\title{
PENGARUH MOTIVASI SPIRITUAL KARYAWAN TERHADAP KINERJA RELIGIUS: STUDI EMPIRIS DI KAWASAN INDUSTRI RUNGKUT SURABAYA (SIER)
}

\author{
Muafi \\ Fakultas Ekonomi \\ Universitas Pembangunan Nasional "Veteran" \\ Yogyakarta
}

\begin{abstract}
Penelitian ini bertujuan untuk mengetahui pengaruh motivasi spiritual terhadap kinerja religius karyawan di kawasan industri Rungkut Surabaya (SIER). Hipotesis yang diajukan dalam penelitian ini adalah (a) motivasi akidah, motivasi ibadah, motivasi muamalat berpengaruh secara serempak terhadap kinerja religius, (b) motivasi muamalat memiliki pengaruh dominan terhadap kinerja religius, (c) ada perbedaan kinerja karyawan operasional dan non operasional di Kawasan Industri Rungkut Surabaya (SIER). Subjek (sampel) dalam penelitian ini adalah karyawan Kawasan Industri Rungkut Surabaya (SIER) berjumlah 110 orang (sampel). Metode penarikan sampel secara non probabilitis dengan purposive sampling. Data diperoleh melalui data primer dengan cara membagikan pertanyaan untuk ditanggapi dan melalui wawancara. Data sekunder yakni melalui catatan dan profil perusahaan. Analisis data dilakukan dengan menggunakan analisis regresi berganda dan uji beda independent sample $t$ test.

Hasil penelitian menunjukkan bahwa (a) motivasi spiritual: motivasi akidah, motivasi ibadah dan motivasi muamalat secara bersama-sama berpengaruh terhadap kinerja religius, (b) motivasi muamalat memiliki pengaruh dominan terhadap kinerja religius, dan (c) tidak ada perbedaan kinerja religius antara karyawan operasional dan non operasional di Kawasan Industri Rungkut Surabaya (SIER)
\end{abstract}

Kata kunci: motivasi spiritual, kinerja religius.

\section{PENDAHULUAN}

Sejak lama Surabaya memiliki potensi yang mendukung berkembangnya lingkungan perindustrian. Dalam kenyataan, potensipotensi itu telah diaktualkan. Angka pertumbuhan sektor industri dari waktu ke waktu terus meningkat. Di Surabaya kini terdapat kurang lebih 9.233 pabrik, baik besar maupun kecil yang menyerap 205.029 karyawan (www.surabaya.go.id). Dari perusahaan yang ada di Jawa Timur tersebut, ada 285 perusahaan berada di kawasan industri Rungkut (SIER) dan 99 perusahaan berada di kawasan Berbek (www.ptsier.com). Fenomena ini mendorong perusahaan untuk terus bersaing secara kompetitif di era yang turbulen seperti sekarang. Dalam lingkungan bisnis yang turbulen, pelipatgandaan kinerja organisasi perusahaan tidak dapat dilakukan hanya dengan kerja lebih keras (work harder), namun diperlukan kerja yang lebih 
cerdas (work smater). Kekayaan organisasi perusahaan dapat dilipatgandakan dengan cara meningkatkan kualitas human capital, di mana salah satunya dapat dicapai melalui peningkatan motivasi karyawan yang secara signifikan akan berpengaruh pada kinerja perusahaan. Karyawan harus memiliki keyakinan bahwa peningkatan kinerja mempunyai manfaat buat diri karyawan sendiri dan perusahaan. Potensi karyawan yang besar dapat dibangkitkan melalui motivasi.

Maslow mengakui bahwa untuk mencapai aktualisasi diri sebagai tingkatan motivasi yang paling tinggi adalah dengan cara memuaskan empat kebutuhan yang berada pada tingkatan yang ada di bawahnya. Orang yang mengaktualisasikan diri lebih didorong oleh metamotivasi (metamotivation). Konsep metamotivasi merupakan pendekatan humanistik yang mengakui eksistensi agama. Mystical atau peak experience merupakan bagian dari metamotivasi yang memberikan gambaran pada pengalaman keagamaan. Pada kondisi ini manusia merasakan adanya pengalaman keagamaan yang sangat dalam. Pribadi (self) lepas dari realitas fisik dan menyatu dengan kekuatan transendental. Tingkatan ini adalah bagian dari kesempurnaan manusia. Oleh karenanya, Maslow membagi dua klasifikasi motivasi: motivasi primer dan motivasi spiritual. Kebutuhan spiritual merupakan kebutuhan yang fitri yang pemenuhannya tergantung pada kesempurnaan manusia dan kematangan individu (Ancok, 1995; Najati, 1982). Nampaknya ada kontribusi yang besar tentang pentingnya spiritual seseorang yang berpengaruh pada psikis seseorang dalam bekerja, di mana secara signifikan akan berpengaruh dengan peningkatan kinerjanya (McCormick., Donald W, 1994; Strawbridge, William J. et al, 1997; Mitroff, Ian I., Elizabeth A Denton, 1999; Lewis, Jefrey S., Gary D. Geroy, 2000).

Pada kenyataannya, secara umum karyawan terus didorong oleh kebutuhan-kebutuhan universal yang tersusun mulai tingkat yang paling bawah sampai dengan yang tertinggi dan biasanya cenderung mengabaikan motivasi spiritual dalam hidupnya. Masalahnya adalah karyawan sebagai individu cenderung selalui ingin melayani kepentingannya sendiri dan bila mereka tidak berbuat demikian maka perilaku mereka dapat dikatakan tidak kondusif bagi efisiensi yang optimal dalam penggunaan sumber daya (Chapra, 2000). Negara-negara Eropa yang demokratis, aman dan makmur, juga Amerika serikat yang menguasai ekonomi dunia, merupakan negara-negara yang selalu mengalami kegoncangan jiwa. Hal ini disebabkan karena mereka lebih menekankan pada dimensi luar tingkah laku manusia dan mengabaikan dimensi spiritualitas (Fromm, 1960 dalam Mursi, 1997; Najati, 1982; Lewis, Jefrey S., Gary D. Geroy, 2000). Perbedaan metode motivasi Barat dengan Islam, bahwa Islam disamping memberikan insentif material dan keuangan juga 
menggunakan insentif spiritual. Insentif spiritual terbukti diyakini lebih kuat daripada material. Hal ini bukan berarti mengabaikan motivasi material dan keuangan. Kajian empiris mengenai pentingnya motivasi spiritual disamping material diteliti juga oleh Mitroff, lan I dan Elizabeth A Denton (1999).

Jawa Timur yang mayoritas masyarakatnya beragama muslim memiliki potensi yang luar biasa dalam upaya mengembangkan dan meningkatkan motivasi spitual karyawannya. Potensi masyarakat muslim yang menjadi sumber daya perusahaan di kawasan SIER tentunya diharapkan dapat digunakan untuk meningkatkan kinerja karyawannya secara religius. Tetapi nampaknya fenomena yang terjadi di kawasan SIER dan sekitarnya adalah masih banyaknya perilaku yang tidak religius, seperti: karyawan perusahaan khususnya wanita masih banyak yang menggunakan pakaian yang tidak menutup aurat (pakaian mini), digunakannya wanita untuk melayani masyarakat setempat dengan menonjolkan unsur seksual, misalnya jasa perbankan, supermarket dan lainnya, jumlah tenaga kerja wanita remaja terpusat pada satu tempat sehingga berdampak psikologis bagi tatanan sosial, budaya perusahaan yang rata-rata berorientasi pada pencapaian keuntungan semata, tingkat kejahatan yang terjadi di siang maupun malam hari dan perilaku lainnya. Perilaku dan pandangan hidup karyawan/perusahaan yang sekuler dan materialistis cenderung mempengaruhi karyawan dan perusahaan untuk bertindak semaunya tanpa memperdulikan kepentingan masyarakat. Banyak perusahaan bersaing untuk menguasai sumber daya, melakukan eksploitasi karyawan yang berlebihan, tidak ramah lingkungan dan perilaku tidak religius lain yang akhirnya akan dapat mempengaruhi perilaku karyawannya. Karyawan perusahaan sekarang ini cenderung hanya mengejar kebutuhan primer, sekunder dan tersier. Hal ini disebabkan karena pemahaman karyawan dan pimpinan perusahaan mengenai motivasi spiritual seperti: motivasi akidah, motivasi ibadah dan motivasi muamalat belum sepenuhnya diterapkan secara kaffah. Oleh karenanya, sejalan dengan fakta empirik yang terjadi perlu dilakukan kajian penelitian yang mendalam mengenai pentingnya pengaruh motivasi spiritual terhadap kinerja religius di kawasan industri Rungkut Surabaya. Berdasarkan uraian di atas, maka rumusan masalah dalam penelitian ini adalah: (a) apakah motivasi akidah, motivasi ibadah dan motivasi muamalat berpengaruh secara serempak terhadap kinerja religius karyawan di kawasan industri Rungkut Surabaya?, (b) motivasi apakah yang mempunyai pengaruh dominan terhadap kinerja religius karyawan di kawasan industri Rungkut Surabaya?, (c) apakah ada perbedaan kinerja religius karyawan operasional dan non operasional di kawasan industri Rungkut Surabaya? 


\section{MOTIVASI SPIRITUAL}

Para pakar psikologi modern tidak banyak yang memberikan perhatian pada studi-studi dimensi spiritual manusia dan kebutuhankebutuhan pokok pada tingkat tinggi. Padahal kebutuhan-kebutuhan ini mempunyai kedudukan terpenting dan tertinggi yang melebihkan manusia dari seluruh ciptaan Tuhan yang lain (Najati, 1982). Sesungguhnya kebutuhan-kebutuhan spiritual bersifat azasi maka seharusnya para pakar psikologi modern juga perlu memperhatikan nilai-nilai spiritual dengan mendalami, menanamkan dan menyusun dasar-dasar moralitas manusia. Di Jepang, terkenal memiliki sikap religiusitas dan etos kerja yang terkenal dengan Budhisme Zen. Kerja bagi mereka bukanlah semata-mata aktivitas ekonomi melainkan amal shaleh secara zen (Rahardjo, 1989). Masyarakat Jepang dikenal memiliki sikap makoto (sincerety), merupakan ajaran dari agama Budha yaitu sikap yang menjunjung tinggi kemurnian dalam batin dan motivasi. Demikian juga dalam pandangan agama lain diyakini bahwa agama Islam, Katolik, Protestan, Hindu, Budha mempunyai ajaran yang sempurna (Marbun, 1986). Didalamnya pasti mengajarkan nilai-nilai moral spiritual yang bermanfaat bagi pemeluknya. Berkaitan dengan aktivitas pekerjaan, Max Weber mengatakan bahwa ada suatu hubungan langsung (fungsional) antara sistem nilai suatu agama dengan kegairahan bekerja para pemeluk agama tersebut (Swasono, 1988).

Dalam kondisi sekarang ada indikasi meningkatnya spiritualisme terutama di kalangan masyarakat Amerika. Sebagaian besar masyarakat Amerika mulai percaya bahwa Tuhan adalah kekuatan spiritual yang positif dan aktif (Kahmat, 2000; Mitroff, Ian I., Elizabeth A Denton, 1999). Pertama kali, Max Weber mengkaji hubungan etos kerja dengan agama. Salah satu hasil dari penelitiannya mengatakan bahwa agama ternyata mampu membangun dan meningkatkan kekuatan kerja serta motivasi menuju pada kenyataan yang riil. Clifford Geertz sebagai penerus Max Weber (dalam Swasono, 1988) juga melakukan penelitian di Kota Gede Yogyakarta. Hasil penelitiannya membagi masyarakat Islam di Kota Gede Yogyakarta menjadi tiga golongan: santri, abangan dan priyayi. Ternyata golongan santri yang melaksanakan ajaran Islam secara puritan (shaleh) bersemangat memiliki aktivitas perdagangan dan industri yang tinggi. Sedangkan dua golongan yang lain: abangan dan priyayi menunjukkan tingkat kegiatan ekonomi yang umumnya tidak bergairah dan tidak dinamis. Hal ini karena dua golongan tersebut memiliki motivasi spiritual yang rendah. Burhanudin dan Natsir juga pernah meneliti pengaruh ajaran tarekat Qadariah Naqsibandiyah (TQN) terhadap perilaku ekonomi para penganutnya. Hasil penelitiannya mengatakan bahwa keyakinan teologis yang berakar pada ajaran tersebut berimplikasi positif terhadap etos kerja 
para penganutnya (Kahmat, 2000). Lebih khusus, terkait dengan aktivitas ibadah Nizami dalam Ancok (1995) juga mengkaji pentingnya shalat yang penuh aktivitas, fisik dan ruhani dapat mengantarkan si pelaku dalam kondisi seimbang jiwa dan raga, sehingga akan berpengaruh terhadap kinerja. Demikian juga dengan Shaleh (2000), mengkaji tentang pentingnya shalat tahajud terhadap peningkatan perubahan respon ketahanan tubuh imunologik. Hal ini tentunya akan mempengaruhi aspek jasmani dan ruhani individu karena berarti individu memiliki motivasi ibadah yang baik sehingga diharapkan kinerjanya akan meningkat. Penelitian Beehr, Johnson dan Nieva (1995) menyimpulkan bahwa ketaatan beragama (religiosity) juga berhubungan dengan kualitas hidup. Beberapa survey sosial menunjukkan bahwa pemeluk aktif agama lebih puas dengan keseluruhan hidup mereka dibanding pemeluk yang tidak aktif (Beit Hallami \& Argyle, 1997). Salah satu dari empat pendekatan model organisasi yang berorientasi pada spiritualitas dan agama, menjelaskan bahwa agama dan spiritualitas memiliki pengaruh positif terhadap perilaku kerja karyawannya. Hal ini karena adanya persahabatan dengan sesama pemeluk agama sehingga dapat menyediakan dukungan sosial yang mengarah pada peningkatan kebahagian dan kesehatan mental, sehingga secara signifikan akan meningkatkan kinerja (Mitroff, Ian I., Elizabeth A Denton, 1999).

Banyak penelitian telah meyakini bahwa aktivitas keagamaan memang dapat menenangkan dan menyamankan seseorang sehingga seseorang dapat merasakan kebahagian, kepuasan hidup, moral maupun kualitas hidup (Beit Hallahmi, B \& Argyle, 1997). Allport dan Ross (1967 dalam Beit Hallahmi, B \& Argyle, 1997) menjelaskan bahwa ada dua sikap ketaatan beragama dalam individu yaitu: intrinsik dan ekstrinsik. Intrinsik berarti bahwa agama sebagai akhir dari segalanya, sehingga individu merasa sangat mempercayainya dan sangat serius terhadapnya. Sedangkan ekstrinsik berarti melihat agama dari permukaan saja. Dalam sikap intrinsik, agama dipercaya dapat menjawab pertanyaan tentang perilaku kehidupan dan mengkaitkan agama dalam seluruh perbuatannya, termasuk motivasi bekerja. Sikap intrinsik ini akan berhubungan positif dengan kesehatan mental aktif (Park, 1990 dalam Beit Hallahmi, B \& Argyle, 1997).

Makna bekerja bagi seorang muslim adalah suatu upaya yang sungguh-sungguh dengan mengerahkan seluruh aset, fikir dan dzikir untuk mengaktualisasikan sebagai hamba Allah yang harus menundukkan dunia sebagai bagian dari masyarakat yang terbaik/khoiro ummah (Tasmara, 1995). Seorang muslim harus meyakini bahwa bekerja itu bukan saja untuk memuliakan dirinya, menampakkan kemanusiannya tetapi juga sebagai suatu manifestasi dari amal shaleh dan oleh karenanya mempunyai nilai ibadah yang luhur. Oleh karenanya, pribadi muslim yang qonaah 
seharusnya memiliki motivasi yang positif dan kuat untuk bekerja dengan sebaik-baiknya, mencurahkan segenap potensi dan kemampuan yang dimiliki agar menghasilkan prestasi/kinerja yang tinggi. Gymnastiar (2002) juga mengatakan bahwa untuk menjadi muslim yang prestatif, seorang muslim harus mensinergikan keunggulan harmoni antara dzikir, fikir dan ihtiar. "Maka, apabila kamu telah selesai (dari suatu urusan), kerjakankan dengan sungguh-sungguh (urusan) yang lain. Dan hanya kepada Tuhanmulah hendaknya kamu berharap" (Q.S Alam Nasyrah (94): 7-8).

Selanjutnya, Anshari (1993) menjelaskan bahwa motivasi spiritual seorang muslim terbagi menjadi tiga: motivasi akidah, motivasi ibadah dan motivasi muamalat. Motivasi akidah adalah keyakinan hidup, yaitu pengikraran yang bertolak dari hati. Jadi, motivasi akidah dapat ditafsirkan sebagai motivasi dari dalam yang muncul akibat kekuatan akidah tersebut. Allport dan Ross (1967, dalam Beit Hallahmi, B \& Argyle, 1997) lebih menyebut motivasi akidah tersebut sebagai sikap intrinsik. Dimensi akidah ini menunjuk pada seberapa besar tingkat keyakinan muslim terhadap ajaran-ajaran yang bersifat fundamental dan dogmatik. Isi dimensi keimanan mencakup iman kepada Allah, para Malaikat, Rasul-Rasul, kitab Allah, surga dan neraka, serta qadha dan qadar. Ibadah merupakan tata aturan Illahi yang mengatur hubungan ritual langsung antara hamba Allah dengan Tuhannya yang tata caranya ditentukan secara rinci dalam Al Qur'an dan Sunnah Rasul (Anshari, 1993). Sedangkan motivasi ibadah merupakan motivasi yang tidak pernah dilakukan oleh orang yang tidak memiliki agama, seperti sholat, doa, dan puasa. Ibadah selalu bertitik tolak dari aqidah. Jika dikaitkan dengan kegiatan bekerja, ibadah masih berada dalam taraf proses, sedangkan output dari ibadah adalah muamalat. Muamalat merupakan tata aturan Illahi yang mengatur hubungan manusia dengan sesama manusia dan manusia dengan benda atau materi (Anshari, 1993). Motivasi muamalat ini berarti mengatur kebutuhan manusia seperti: kebutuhan primer (kebutuhan pokok), sekunder (kesenangan) dengan kewajiban untuk dapat meningkatkan kinerja dan kebutuhan primer (kemewahan) yang dilarang oleh Islam. Oleh karenanya manusia diharapkan dapat bekerja dan berproduksi sebagai bagian dari muamalat menuju tercapainya rahmatan lil alamin. Disimpulkan bahwa tuntutan akan kebutuhan spiritual begitu mendesak bagi kemanusiaan universal sehingga dalam persoalan-persoalan yang paling sederhana sekalipun harus diupayakan tetap menuju pada alur spiritualitas. Oleh karenanya kajian motivasi spiritual sangat penting dalam upaya meningkatkan kinerja yang religius. 


\section{KINERJA RELIGIUS}

Dalam sepanjang sejarah perjalanan hidup manusia, salah satu fenomena yang terjadi adalah religiusitas. Religiusitas ini selalu diwujudkan dalam sisi kehidupan manusia. Religiusitas seseorang akan meliputi berbagai dimensi: dimensi keyakinan (ideologis), dimensi peribadatan (ritualistik), dimensi penghayatan (eksperiensial), dimensi pengamalan (konsekuensial) dan dimensi pengetahuan agama (Ancok, 1995). Dimensi keyakinan berisikan harapan-harapan dimana seseorang yang religius berpegang teguh pada pandangan teologis tertentu dan mengakui kebenaran-kebenaran doktrin agamanya. Dimensi agama berisikan perilaku ritual keagamaan, ketaatan dari seseorang yang religius di mana menunjukkan komitmen terhadap agama yang dianutnya. Dimensi penghayatan berisikan pengalaman-pengalaman, persepsi yang dialami seseorang dalam beragama. Dimensi pengetahuan agama mengacu pada orang-orang religius yang minimal memiliki pengetahuan mengenai dasardasar keyakinan, kitab suci dan tradisi. Sedangkan dimensi pengamalan adalah akibat-akibat keyakinan keagamaan, praktek, pengamalan dan pengetahuan seseorang dari hari ke hari.

Berkaitan dengan kinerja perusahaan merupakan hasil dari semua laporan manajemen yang dilakukan secara terus menerus (Helfert, 1991). Sedangkan, menurut Prawirosentono (1997) kinerja adalah hasil kerja yang dapat dicapai oleh seseorang atau sekelompok orang dalam suatu organisasi, sesuai dengan wewenang dan tanggung jawab masing-masing, dalam upaya mencapai tujuan organisasi bersangkutan secara legal, tidak melanggar hukum dan sesuai dengan moral maupun etika. Dalam pandangan Islam, menilai kinerja religius seseorang dapat dilihat dari beberapa indikator (Zadjuli, 1999) antara lain: niat bekerjanya adalah karena Allah, dalam bekerja menerapkan kaidah/norma/syariah secara kaffah, motivasinya adalah spiritual dengan mencari 'keberuntungan' di dunia dan akherat, menerapkan asas efisiensi dan manfaat dengan tetap menjaga kelestarian hidup, menjaga keseimbangan antara mencari harta dengan beribadah, bersyukur kepada Allah dengan cara tidak konsumtif, mengeluarkan ZIS, dan menyantuni anak yatin dan fakir miskin. Sebagai konsekuensi atas sempurnanya manusia sebagai mahluk Allah maka manusia dituntut untuk bekerja dengan sebaik-baiknya (dengan sungguhsungguh). Kinerja yang religius selalu melibatkan ilmu pengetahuan dan teknologi sehingga kualitas kinerja religius tidak sama dengan kinerja biasa. Oleh karenanya, manusia sangat disarankan untuk dapat menguasai ilmu pengetahuan dan teknologi agar bisa menjadi manusia yang prestatif dan bermanfaat untuk kepentingan umat di dunia. Dalam Q.S As Zumar ayat 9: "Katakanlah: samakah orang-orang yang berilmu pengetahuan 
dengan orang-orang yang tidak berilmu pengetahuan?" Hanya orang-orang mengertilah yang dapat memikirkannya.

Kinerja religius sendiri bisa didekati dengan tiga varibel: kinerja fisiologis religius, kinerja psikologi religius dan kinerja spiritual (Wibisono, 2002). Kinerja fisiologi religius berarti individu harus menyadari bahwa alam dan segala isinya harus dimanfaatkan sepenuhnya untuk produksi secara efisien dan efektif, menyadari bahwa individu memiliki kemampuan bekerja dan berproduksi yang harus dikerahkan segala potensinya menuju manusia yang prestatif, teknologi harus dimanfaatkan secara tepat guna dan ramah lingkungan, serta menyadari sepenuhnya bahwa modal adalah sebagai salah satu faktor produksi yang harus dimanfaatkan secara efisien dan terbebas dari riba. Kinerja psikologi religius berarti individu harus menyadari bahwa kesehatan adalah anugerah yang harus dimanfaatkan untuk bekerja dan berproduksi, hubungan sosial dengan rekan sekerja/kelompok kerja harus harmonis untuk meningkatkan kinerja, penghargaan (hadiah) harus disyukuri sebagai perwujudan dari reward dan hukuman harus dilaksanakan dengan ihlas dan berjanji untuk tidak mengulangi kesalahan sebagai perwujudan dari punishment perusahaan serta terus meningkatkan kualitas diri (aktualisasi diri) guna meningkatkan kinerja. Sedangkan kinerja spiritual berarti individu harus menyadari bahwa tawakal kepada Allah harus dibarengi dengan ihtiar, bekerja dan berproduksi, jujur dalam bekerja dan berproduksi, menjaga kualitas pekerjaan, dan bekerja dan berproduksi dengan ihlas karena Allah.

\section{KERANGKA PEMIKIRAN DAN HIPOTESIS.}

Penelitian ini memasukkan teori tentang salah satu motivasi yang bukan merupakan motivasi yang didorong oleh kebutuhan primer (pokok) maupun kebutuhan sekunder (kesenangan), apalagi tersier (kemewahan). Motivasi yang ditekankan dalam penelitian ini adalah motivasi spiritual. Dalam berbagai kajian penelitian, masih jarang sekali ditemui literatur tentang motivasi spiritual tersebut. Hanya saja berbagai penelitian secara garis besar memang mendukung suatu pernyataan bahwa ketaatan beragama dapat menenangkan dan menyamankan seseorang sehingga seseorang dapat merasakan kebahagian, kepuasan hidup, moral maupun kualitas hidup (Beit Hallami \& Argyle, 1997; Mitroff., Ian I., Elizabeth A Denton, 1999). Penelitian ini merupakan replikasi dari penelitian Wibisono (2002) yang ingin menguji pengaruh motivasi spiritual terhadap kinerja karyawan industri manufaktur di Batamindo Batam. Dengan menggunakan tehnik statistik SEM (Amos), hasil dari penelitian Wibisono (2002) menyimpulkan bahwa ada pengaruh motivasi spiritual: akidah, ibadah dan muamalat terhadap kinerja religius, meskipun motivasi ibadah memiliki 
pengaruh negatif terhadap kinerja religius. Dalam penelitian ini disamping ingin melihat pengaruh secara bersamaan maupun parsial dari motivasi spiritual terhadap kinerja religius, juga dikembangkan dengan menguji perbedaan kinerja karyawan dilihat dari karyawan operasional dan non operasional di kawasan industri Rungkut Surabaya. Oleh karenanya, kerangka pemikiran dalam penelitian ini dapat dilihat pada gambar 1.

Dengan mendasarkan pada rumusan masalah, teori dan kerangka pemikiran di atas, maka hipotesis dalam penelitian ini adalah: (a) ada pengaruh motivasi akidah, motivasi ibadah dan motivasi muamalat secara bersama-sama terhadap kinerja religius, (b) motivasi muamalat memiliki pengaruh dominan terhadap kinerja religius, (c) ada perbedaan kinerja karyawan operasional dan non operasional di kawasan industri Rungkut Surabaya.

Gambar 1.

Kerangka Pemikiran Penelitian

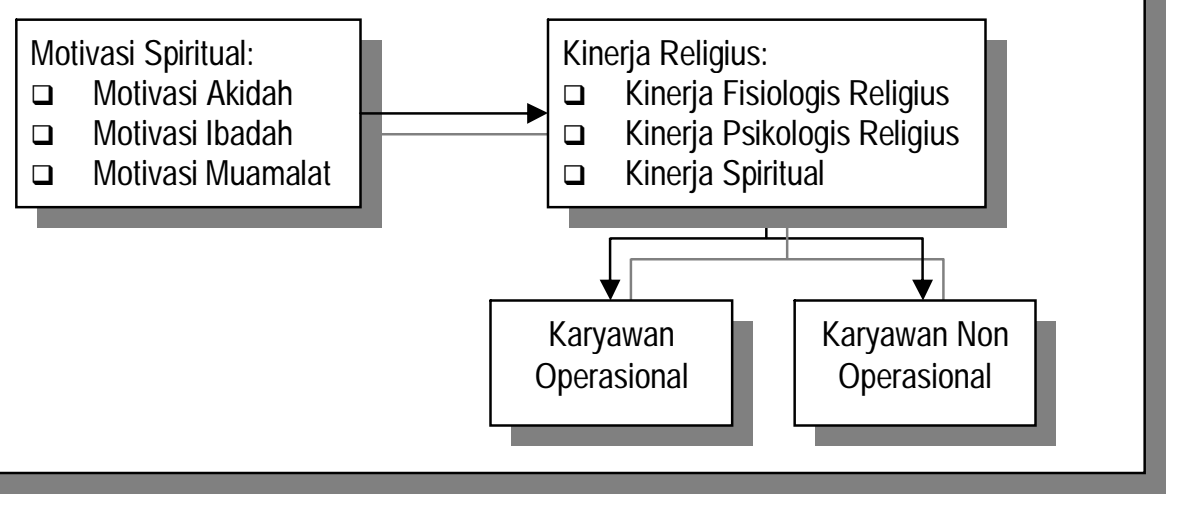

\section{METODE PENELITIAN}

Dalam penelitian ini digunakan empat variabel penelitian antara lain: a) Kinerja religius, sebagai variabel terikat $(Y)$ dan motivasi spiritual sebagai variabel bebas, terdiri dari: motivasi akidah (X1), motivasi ibadah (X2) dan motivasi muamalat (X3). Motivasi akidah terdiri dari tiga indikator: iman kepada Allah, iman kepada Kitab Allah, iman kepada Rasul Allah. Masing-masing indikator terdiri dar lima item pertanyaan sehingga jumlah keseluruhan item untuk variabel motivasi akidah adalah 15. Motivasi ibadah terdiri dari tiga indikator: tingkat pengamalan doa, sholat, dan puasa. Masing-masing indikator terdiri dari lima item pertanyaan sehingga jumlah keseluruhan item untuk variabel motivasi ibadah adalah 15. Motivasi 
muamalat terdiri dari tiga indikator: kebutuhan primer (sandang, papan, pangan), kebutuhan sekunder (kesehatan, pendidikan dan kesenangan), dan kebutuhan bekerja serta berproduksi. Masing-masing indikator terdiri dari lima item pertanyaan sehingga jumlah keseluruhan item untuk variabel motivasi ibadah adalah 15 . Sedangkan kinerja religius terdiri dari tiga indikator: kinerja fisiologi religius, kinerja psikologi religius dan kinerja spiritual. Masing-masing indikator memiliki empat item pertanyaan sehingga jumlah keseluruhan item pertanyaan untuk kinerja religius adalah 16 item pertanyaan. Keseluruhan jumlah item pertanyaan baik untuk variabel motivasi akidah, motivasi ibadah, motivasi muamalat dan kinerja religius adalah 61 item. Uji reliabilitas menggunakan Cronbach Alpha. Dalam penelitian ini keseluruhan variabel menghasilkan Cronbach Alpha di atas 0,6 sehingga dianggap reliabel. Uji validitas dilakukan dengan menggunakan program SPS Sutrisno Hadi. Keseluruhan butir adalah sahih. Hal ini dimungkinkan mengingat pertanyaan yang diajukan sudah terstandarisasi sesuai dengan penelitian Wibisono (2002).

Skala pengukuran dalam penelitian ini adalah skala ordinal. Model skala Likert digunakan dengan lima jawaban, yaitu: (SS) sangat setuju skor 5, (S) setuju skor 4, (T) netral skor 3, (TS) tidak setuju skor 2, dan (STS) sangat tidak setuju skor 1. Skala ukur yang digunakan dalam penelitian ini memang menggunakan skala ordinal, tetapi menurut Sugiyono (1999) data ordinal yang menggunakan tehnik skala Likert adalah data interval karena dianggap memiliki jarak yang sama. Hal ini juga pernah dilakukan oleh peneliti lain seperti Badri et al., (2000), dan Schull et al., (1995) dan Muafi (2002) yang dalam penelitiannya menggunakan model analisis jalur (regresi jalur) dengan skala ordinal. Jenis data yang digunakan adalah data primer diperoleh melalui daftar pertanyaan yang telah diisi oleh responden dan data sekunder dari catatan dan profil perusahaan.

Subjek penelitian adalah karyawan operasional dan non operasional di kawasan industri Rungkut Surabaya yang beragama muslim. Alasan digunakan karyawan muslim adalah karena aspek spiritual yang ditegaskan dalam penelitian ini adalah menurut konsep Islam. Hal ini bukan berarti aspek spiritual dalam agama lain tidak penting. Sedangkan alasan lain diambilnya karyawan operasional dan non operasional karena secara umum karyawan operasional dan non operasional memiliki tingkat pendidikan yang berbeda. Karyawan operasional dianggap memiliki tingkat pendidikan yang lebih tinggi dibandingkan karyawan non operasional. Oleh karenanya pengetahuan, pemahaman dan pengamalan motivasi akidah, ibadah dan muamalat diduga lebih baik daripada karyawan non operasional. Disamping itu pendekatan keperilakuan (unsur psiokologis) akan lebih berkaitan pada karyawan operasional di bandingkan dengan karyawan non operasional (Anthony, 1992). Kuesioner disebarkan kepada 
karyawan pada saat telah menyelesaikan sholat di tempat peribadatan baik di masjid maupun mushola di sekitar kawasan industri Rungkut Surabaya. Hal ini dimaksudkan agar karyawan berhati-hati dalam mengisi kuesioner dan betul-betul menghayati tentang pentingnya memiliki motivasi spiritual dalam peningkatan kinerja religius, setelah melakukan ibadah ritual.

Dalam penelitian ini karyawan operasional dan non operasional yang diteliti (sampel) adalah sebanyak 120 orang. Hal ini sudah memenuhi syarat bahwa untuk penelitian survei minimum adalah 30 orang (Gay dan Diehl 1992). Sampel diambil dengan tehnik non probabilitas, yakni purposive sampling. Pengambilan sampel didasarkan pada pertimbangan penyesuaian diri dengan kriteria penelitian tertentu sehingga dapat meningkatkan ketepatan sampel (Cooper dan Emory, 1995). Adapun kriteria yang digunakan dalam penelitian ini adalah: responden minimal telah bekerja 2 tahun. Saat mengisi kuesioner dilakukan setelah melaksanakan sholat. Kuesioner yang dikembalikan adalah 120 kuesioner, sehingga tingkat responsnya sebesar $100 \%$. Kuesioner yang dijawab lengkap 110 kuesioner dan layak untuk dianalisis. Model analisis yang digunakan untuk mengetahui pengaruh adalah Regresi Berganda dengan program SPSS dan SPS Sutrisno Hadi. Sedangkan untuk melihat perbedaan kinerja religius karyawan operasional dan non operasional digunakan uji independent sample $t$ test, dengan jumlah karyawan operasional dan non operasional masing-masing 55 karyawan.

\section{HASIL PENELITIAN DAN PEMBAHASAN}

Dengan menggunakan analisis regresi berganda ternyata motivasi akidah (X1), motivasi ibadah (X2) dan motivasi muamalat (X3) berpengaruh secara serempak terhadap kinerja. Ini berarti hipotesis pertama terbukti. Karena $F$ hitung $=28,12>F$ tabel 2,70 (alfa 0,05) dengan tingkat signifikansi 0,000 jauh lebih kecil dari 0,05. Sehingga dapat disimpulkan bahwa motivasi akidah, motivasi ibadah dan motivasi muamalat secara serempak/bersama-sama berpengaruh terhadap kinerja. Ini berarti hipotesis pertama diterima. Demikian juga $42,70 \%$ variasi dari kinerja religius bisa dijelaskan oleh variasi dari ketiga variabel motivasi spiritual: motivasi akidah, ibadah dan muamalat. Sedangkan sisanya (100\%-42,70= $57,30 \%)$ dijelaskan oleh variasi variabel yang lain. Untuk Standar Error of Estimasi (SEE) adalah 32,17\%. Makin kecil SEE model regresi yang dipakai disini berarti semakin tepat dalam memprediksi variabel kinerja religius. Untuk lebih jelas dapat dilihat pada tabel 1. 
Tabel 1.

Anova

\begin{tabular}{l|r|r|r|c|c|}
\hline \multicolumn{1}{|c|}{ Model } & \multicolumn{1}{c|}{ DF } & Sum of Square & Mean Square & F & Signif F \\
\hline Regression & 3 & 8,728 & 2,909 & 28,121 & 0,0000 \\
Residual & 106 & 10,967 & 0,103 & & \\
\hline a0,05 & $=2,70$ \\
R square & $=0,443$ \\
Adjusted R Square & $=0,427$ \\
Standart Error $\quad=0,3217$ &
\end{tabular}

Sedangkan untuk melihat pengaruh masing-masing variabel motivasi spiritual terhadap kinerja religius dan variabel motivasi spititual yang dominan terhadap kinerja dapat dilihat pada tabel 2.

Tabel 2.

Hasil Perhitungan

Variables in the Equation

\begin{tabular}{|c|c|c|c|c|c|}
\hline Sig T & Variable & B & SE B & Beta & T \\
\hline, $0000^{*}$ & $\mathrm{X} 1$ & 0,198 &, 052 &, 287 & 3,813 \\
\hline, $0000^{*}$ & $\mathrm{X} 2$ & 0,189 &, 033 &, 430 & 5,663 \\
\hline, $0000^{*}$ & $\mathrm{X} 3$ & 0,539 &, 073 &, 541 & 7,394 \\
\hline, 0000 & (Constant) & 1,992 &, 089 & & 5,118 \\
\hline
\end{tabular}

Keterangan: * siginifikansi 5\% dan 1\%.

Dari tabel di atas dapat dijelaskan persamaan regresi sebagai berikut :

$$
Y=1,992+0,198 \times 1+0,189 \text { X2 + 0,539 X3 }
$$

Dimana:

$Y=$ kinerja religius,

$\mathrm{X} 1$ = motivasi akidah,

$\mathrm{X} 2$ = motivasi ibadah,

$\mathrm{X} 3=$ motivasi muamalat .

Konstanta sebesar 1,992 menyatakan bahwa jika tidak ada motivasi akidah, motivasi ibadah dan motivasi muamalat maka kinerja religius adalah 19,92\%. Koefisien regresi X1 sebesar 0,198 menyatakan bahwa setiap penambahan $1 \%$ motivasi akidah maka akan meningkatkan kinerja religius sebesar $19,8 \%$, jika motivasi ibadah dan motivasi muamalat dianggap konstan. Koefisien regresi X2 sebesar 0,189 menyatakan bahwa setiap penambahan $1 \%$ motivasi ibadah maka akan meningkatkan kinerja religius sebesar 18,90\%, jika motivasi akidah dan motivasi muamalat 
dianggap konstan. Koefisien regresi X3 sebesar 0,539 menyatakan bahwa setiap penambahan $1 \%$ motivasi muamalat, maka akan meningkatkan kinerja religius sebesar 53,9\% jika motivasi akidah dan motivasi ibadah dianggap konstan. Jika ingin membandingkan antara statistik t hitung dengan statistik $\mathrm{t}$ tabel, maka dapat dijelaskan sebagai berikut:

a) untuk motivasi akidah, t hitung $=3,813>t$ tabel $=1,96$ (dengan alfa 0,05 ) berarti motivasi akidah berpengaruh secara signifikan terhadap kinerja religius.

b) Untuk motivasi ibadah, t hitung $=5,663>\mathrm{t}$ tabel $=1,96$ (dengan alfa 0,05 ) berarti motivasi ibadah berpengaruh secara signifikan terhadap kinerja religius.

c) Untuk motivasi muamalat, $t$ hitung $=2,898>t$ tabel $=1,96$ (dengan alfa 0,05 ) berarti motivasi muamalat berpengaruh secara signifikan terhadap kinerja religius. Hasil perhitungan SPSS koefisien regresi yang terbesar adalah motivasi muamalat $=0,539$, sehingga dapat disimpulkan bahwa motivasi muamalat berpengaruh secara dominan terhadap kinerja religius. Ini berarti hipotesis yang kedua diterima.

Selanjutnya dengan menggunakan uji independent sample $t$ test, ternyata tidak ada perbedaan kinerja antara karyawan operasional dan non operasional, dengan probabilitas 0,000 , sehingga hipotesis ketiga yang diajukan tidak diterima/ditolak.

Dari hasil penelitian jelas menunjukkan bahwa temuan penelitian ini mendukung hasil penelitian sebelumnya. Wibisono (2002) juga membuktikan bahwa ada pengaruh motivasi spiritual terhadap kinerja religius, meskipun dalam penelitian ini variabel motivasi ibadah memiliki pengaruh positif, sedangkan pada penelitian Wibisono (2002) motivasi ibadah memiliki pengaruh negatif. Jika seseorang memiliki akidah yang kuat, maka akan melahirkan keutamaan-keutamaan yang tinggi seperti selalu dermawan, berani, tentram, bahagia yang kesemuanya akan berpengaruh pada kualitas hidup/kinerja religius. Sedangkan, Ancok (1994: 79) mengatakan bahwa dalam melakukan aktivitas ekonomi, sosial, politik atau aktivitas apapun termasuk dalam bekerja seorang muslim diperintahkan untuk melakukankannya dalam rangka beribadah kepada Allah. Tingkat pengamalan doa, sholat dan puasa merupakan karakteristik khas yang seharusnya dimiliki oleh setiap pribadi muslim yang memberikan dorongan pada diri karyawan untuk berkinerja secara religius. Potensi doa, dzikir dan pikir adalah aset Illahiyah yang seharusnya dikelola dengan baik dalam mewujudkan prestasi kerja atau amal shaleh (Tasmara, 1995). Lebih lanjut Gymastiar (2002) menegaskan bahwa untuk menjadi muslim yang 
prestatif (berkinerja tinggi) seorang karyawan harus mensinergikan keunggulan harmoni: dzikir, fikir dan ihtiar/berusaha/bekerja.

Selanjutnya, temuan penelitian ini juga mendukung hasil penelitian Wibisono (2002) yang menemukan bahwa ternyata motivasi muamalat memiliki pengaruh dominan terhadap kinerja religius. Setiap pribadi muslim dituntut untuk bekerja dengan sungguh-sungguh agar dapat memenuhi kebutuhannya yang diridhoi oleh Allah. Membudayakan kebiasaan bekerja akan menjadi salah satu ciri utama setiap pribadi muslim yang menjadikannya sebagai the thought and spirit of time yakni memberikan citra dan semangat yang terus memberikan ilham dalam perjalanan hidup, di mana akan terukir sejarah dan tapak-tapak pribadi muslim yang prestatif. Demikian juga dalam berproduksi, seorang muslim harus memandang kehidupan ini sebagai arena yang memberikan tiga cakupan penting: tantangan, kekuatan, peluang dan perjuangan (Tasmara, 1995).

Temuan yang juga penting dalam penelitian ini adalah ternyata tidak ada perbedaan kinerja karyawan operasional dan non operasional di kawasan industri Rungkut Surabaya. Dugaan bahwa ada perbedaan kinerja karyawan operasional dan non operasional ternyata ditolak. Hal ini memberikan bukti bahwa karyawan non operasionalpun ternyata merasakan pentingnya memiliki motivasi spiritual dalam meningkatkan kinerja religiusnya, sehingga pendekatan keperilakuan diperlukan juga bagi mereka. Bagaimanapun, karyawan non operasional adalah seorang individu (hamba Allah) yang juga ingin diakui keberadaan dan eksistensinya. Ternyata kebutuhan spiritual memang bersifat asasi dan tidak pernah memandang individu dari segi pangkat, jabatan atau status sosial lainnya. Demikian juga religiusitas selalu diwujudkan dalam sisi kehidupan manusia.

IMPLIKASI

Temuan-temuan di atas menimbulkan beberapa implikasi baik implikasi manajerial maupun implikasi untuk penelitian mendatang.

\section{Implikasi Manajerial}

Sebagai suatu penelitian empiris, penelitian ini dapat menghasilkan temuan-temuan yang bermanfaat bagi para pimpinan perusahaan dan karyawan. Dalam paradigma spiritualisme potensi manusia untuk berkinerja harus menjadikan hidup yang lebih positif dan produktif untuk mencapai prestasi kerja yang religius. Pimpinan perusahaan harus memperhatikan motivasi spiritual karyawan. Pentingnya memberikan pengetahuan, pemahaman dan melaksanakan motivasi akidah, ibadah dan muamalat kepada setiap individu agar tercapai kinerja yang tinggi. Hal ini dikarenakan 
selama ini masih banyak sekali pimpinan dan karyawan yang mengabaikan motivasi spiritual tersebut. Perlu disadari bahwa di negara Baratpun sudah semakin banyak yang menyadari pentingnya ketaatan beragama dalam meningkatkan kinerja perusahaan. Bahkan Fritjof Chapra dalam The Way of Life dan The Tao of Physic bertutur bahwa keterpurukan manusia dalam berbagai aspek saat ini ditengarai karena manusia masih terjebak dalam paradigma yang serba mekanistik, paradigma yang menjebak manusia dalam kepongahan yang bodoh. Akar permasalahannya terletak pada keengganan manusia mengakui campur tangan Tuhan, dalam setiap kesuksesan bahkan kegagalan yang terjadi pada dirinya (Manajemen, 2003).

Kelayakan kinerja religius akan tercermin pada hasil produksi yang Islami, kualitas produk dan pelayanan Islami yang bisa bersaing dengan negara maju, efisien dan efektif, serta realisasi kepuasan karyawan yang diridhoi oleh Allah. Oleh karenanya ada beberapa unsur yang harus dilaksanakan pada pencapaian kinerja religius seperti yang dijelaskan oleh Zadjuli (1999), yakni: niat bekerjanya adalah karena Allah, dalam bekerja menerapkan kaidah/norma/syariah secara kaffah, motivasinya adalah spiritual dengan mencari 'keberuntungan' di dunia dan akherat, menerapkan asas efisiensi dan manfaat dengan tetap menjaga kelestarian hidup, menjaga keseimbangan antara mencari harta dengan beribadah, bersyukur kepada Allah dengan cara tidak konsumtif, mengeluarkan ZIS, dan menyantuni anak yatim dan fakir miskin. Disamping itu sebaiknya pimpinan perusahaan mengarahkan karyawan pada perkembangan kepribadian Islami yang produktif, dengan ciri: (a) menyesuaikan kemampuan, keahlian, ketrampilan dan pengalaman khusus pada tuntutan kesuksesan kerja, (b) menerapkan kepribadian muslim dalam menjalankan suatu profesi, dan (c) menjaga kesehatan mental dan ruhani.

\section{Implikasi untuk Penelitian Mendatang}

Dalam penelitian mendatang agar dilakukan di lokasi yang karyawannya merasa nyaman dan tenang dalam beribadah, yang memiliki lokasi penelitian yang bernuansa religius sehingga dapat lebih diamati secara realistis. Demikian juga agar menambah jumlah responden dan memberikan penjelasan yang detail jika responden mengalami kebingungan dalam menjawab kuesioner.

Dalam penelitian ini lebih diarahkan pada motivasi intrinsik (motivasi spiritual) untuk meningkatkan kinerja religius. Jadi untuk penelitian mendatang akan lebih menarik jika pendekatan motivasi ekstrinsik digabungkan untuk melihat pengaruhnya terhadap kinerja religius. Demikian juga aspek kecerdasan spiritual (spiritual quotient) juga perlu dipertimbangkan dalam mempengaruhi kinerja religius. Iverson (1996) juga Guest (1987, 1992, 1995 dalam Mulyono, 2002) menyarankan bahwa 
komitmen organisasi akan memediasi efek kausal menyeluruh atas pengaruh positif, keamanan, kepuasan, motivasi dan kesempatan lingkungan. Oleh karenanya variabel komitmen organisasi bisa dipertimbangkan untuk dimasukkan dalam penelitian selanjutnya.

Untuk melihat perbedaan kinerja religius sebaiknya tidak hanya dilihat dari karyawan operasional dan non operasional saja, melainkan juga bisa ditanyakan kepada karyawan kegiatan keagamaan yang sekiranya bisa mempengaruhi motivasi spiritual karyawan dalam bekerja, misalnya: frekuensi sering tidaknya mengikuti kajian keagamaan dalam seminggu, frekuensi melaksanakan sholat tahajud dalam seminggu, pernah tidaknya melaksanakan puasa sunnah dalam seminggu, pernah tidaknya menunaikan ibadah haji, dan aspek akidah, ibadah dan muamalat lainnya. Disarankan bagi peneliti dari agama lain untuk mengkaji pentingnya motivasi spiritual terhadap kinerja religius dengan pemakaian variabel dan indikator yang disesuaikan dengan agama masing-masing. Hal ini dipastikan bisa dilaksanakan karena semua agama baik Islam, Katolik, Protestan, Hindu dan Budha memiliki ajaran yang sempurna (Marbun, 1986).

\section{DAFTAR PUSTAKA}

Al Qur'an dan Terjemahan

Ancok, Jamaludin (1994), Psikologi Islam, Pustaka Pelajar: Yogyakarta.

Anshari (1993), Wawasan Islam. Pokok-Pokok Fikiran tentang islam dan Ummatnya, Raja Grafindo Persada: Jakarta.

Anthony, Robert N (1992), Sistem Pengendalian Manajemen, Binarupa Aksara: Jakarta.

Badri, Masood A., Donald Davis., and Donna Davis (2000), "Operation strategy, environmental uncertainty and performance: a path analtytic model of industries in developing countries," Omega, 28, p. $155-173$

Beehr, T.A., Johnson, L.B \& Nieva, R (1995). Occupational stress: coping of police and their spouse, Journal of Organizational Behavior, 16, p.3-25.

Beit-Hallahmy \& Argyle (1997), The Psichology of Religious, Behaviour, Belief and Experience, First edition, Routledge: London.

Chapra, Umar (2000), Islam dan Pembangunan Ekonomi, Gema Insani Press: Jakarta. 
Cooper, Donald R and C. William Emory (1995), Business Researh Methods, $5^{\text {th }} \mathrm{Ed}$, Chicago: Richard D. Irwin, Inc.

Gay, L.R., dan P.L. Diehl., 1992. Research Methods for Business and Management, New York; MacMillan Publishing Company.

Gymnastiar, Abdullah (2002), Menjadi Muslim Prestatif. Mensinerginakan keunggulan harmoni dzikir-fikir-ihtiar, MQS Pustaka Grafika: Bandung.

Hadi, Sutrisno., Seno Pamardiyanto, Yuni P. Kuncoro (1996), Seri Program Statistik, Paket Midi, UGM: Yogayakarta.

Halfert, Erich. A (1991), Technique of Financial Analysis, Seventh Edition, Homewood,: Richard D. Irwin Inc., Illinois.

Kahmat, Dadang (1999), Metode Penelitian Agama, Pustka Setia: Bandung.

Lewis, Jefrey S., Gary D. Geroy (2000), Employee Spirituality in the workplace: A cross-cultural view for the management of spiritual employees, Journal of Management Education, Thousand Oaks, Oct, 24: p. 682-694.

Manajemen (2003), Manajemen Holistik. Jawaban Atas Krisis Multidimensi, No. 174, Februari.

Marbun (1996), Manajemen Jepang, Pustaka Binawan Pressindo: Jakarta.

McCormick, Donald W (1994), Spirituality and Management, Journal of Managerial Psychology, Bradford, 9: p. 5-11.

Mitroff, Ian I., Elizabeth A Denton (1999), A Study of spirituality in the workplace, Sloan Management Review, Summer, 40: p. 83-92.

Muafi (2001), Studi empirik Pengaruh Merek Perintis Pada Proses Pemilihan Merek Dan Alasan Berperilaku Beli Terhadap Merek Pilihan, WAHANA, Vol. 4, No. 2, Agustus.

Mulyono, Agung., Dwi Cahyono dan Yusnan Arigayo (2002), Komitmen Organisasi Sebagai Mediasi Hubungan Antara Etika Kerja Islam Dengan Sikap Terhadap Perubahan Organisasi, Simposium Nasional Sistem Ekonomi Islam, P3EI-FEUII, 13-14 Maret.

Mursi, Abdul Hamid (1997), Sumber Daya Manusia yang Produktoif, Gema Insani Press: Jakarta.

Najati, Muhammad Ustman (1982), Al Qur'an wa IIman Nafs, Darus Syuruq: Kairo. (2001), Jiwa Manusia dalam Sorotan Al Qur'an, Cendekia: Jakarta. 
Prawirosentono, Suyadi (1999), Kebijakan Kinerja Karyawan, Edisi Pertama, BPFE, Yogyakarta

Rahardjo, M. Dawam (1989), Budhisme Zen dan Etos Kerja Jepang, Jurnal IImu dan Kebudayaan Ulumul Qur'an, Vol. 1 No. 1.]

Santoso, Singgih (2000), SPSS Statistik Parametrik, Elex Media Komputindo: Jakarta.

Schull, Patrick L., Peter S. Davis and Michael D. Hartline (1995), "Strategic Adaptation to Extended Rivalry," Journal of Business Review, 33, p. $129-142$

Sholeh, Mohammad (2000), Pengaruh Sholat Tahajjud terhadap Peningkatan Perubahan Respon Ketahanan Tubuh Imunologik, Disertasi: Universitas Airlangga Surabaya.

Strawbridge, William J., Richard D Cohen., Sarah J Shema, George A Kaplan (1997), Frequent attendance at religious servives and mortality over 28 years, American Journal of Public Health, Washington, Jun, 87: p. 957-961.

Swasono, Sri Edi (1988), Sekitar Kemiskinan dan Keadilan, UI Press: Jakarta.

Tasmara, Toto (1995), Etos Kerja Pribadi Muslim, Dana Bhakti Wakaf: Jakarta.

www.surabaya.go.id (2004) Industri di Surabaya

www.ptsier.com (2004) PT. Sier Surabaya

Wibisono, Chablullah (2002), Pengaruh Motivasi Spiritual Terhadap Kinerja Karyawan Industri Manufaktur di Batamindo, Disertasi: Universitas Airlangga Surabaya.

Zadjuli (1999), Membentuk Manusia menjadi Khalifah di Bumi yang Makdaniyah, Pusat Studi Kebijakan Alternatif: Surabaya. 